\title{
Social Tourism, Its Clients and Perspectives
}

\author{
Jana Jablonská
}

Matúš Jaremko

Gejza M. Timčák

\author{
Assoc. Professor, Dept. of Mountanous- and Geotourism, Technical University in Kosice, Letná 9, 04200 Kosice, Slovakia \\ Manager, Hilton Prague, Pobrezni 1, Prague, Czech Republic \\ Associate Professor, Technical University Ostrava, Mining College, 17- Listopadu 15, Ostrava, Czech Republic
}

\section{Doi:10.5901/mjss.2016.v7n3s1p42}

\begin{abstract}
This article analyzes the definitions, contents and implementations of the concept of "social tourism". Social tourism is also called tourism for all, because its aim is to involve the whole society in tourism, including disadvantaged people, whether disadvantaged for economic or health reasons. The paper also proposes a definition of social tourism that can effectively set social tourism apart from other forms of tourism and defines the added social benefits. For this population segment it is a substantial problem to travel. It is designed for low-income families, who have the right to travel, but they can't fully exercise this right. In addition to the financial aid of the state, various organizations and associations involved in social tourism contribute to the promotion of social tourism. The region of study vas defined as Slovakia. The paper investigates which organizations search for grant possibilities, create products for social tourism, bring together the objects of social tourism and assist in the promotion and improvement of living and social tourist conditions. The paper reflects the very actual need for securing holiday possibilities for the unprivileged people, and also for migrants and new-settlers. The aim of the paper is to show the strong and weak aspects of social tourism in Slovakia and possible areas of improvement.
\end{abstract}

Keywords: social tourism, disadvantaged persons, low -income families, migrants, asylum.

\section{Introduction}

Social tourism is an area where those in risk of poverty could get a possibility to have a vacation at price levels accessible for them. But neither the general public, nor the potential recipients are usually aware of such a possibility. The paper analyzes the available structures and constructions under which people at risk of poverty usually suffering from social exclusion can participate on social tourism constructions and indicates ways how to improve the efficiency of social tourism provision. Apart from statistical data, the results of a survey are also analyzed. As social tourism is a low preference area for service providers, not infrequently due to cultural habits of the underprivileged segments of population, or in case of people with disabilities for the need of higher intensity of customer care, possible areas of service improvement to the underprivileged segments of population had to be mapped and their contribution to the analyzed problem researched. The present intensity of help through social tourism is being shown and proposals for increasing this intensity are shown.

\section{Origins of Social Tourism and Its Definition}

Tourism in its present form appeared only in the 19th century. At that time, it was accessible to high society elite only, since the laws ruling labour did not include holidays for employees, who had to go to work every day, including Sundays. Therefore, possibilities for most of the population to go on holidays were very limited. The actions for social tourism started in 1936, when the International Labour Organization (ILO) agreed on the Holiday with Pay Convention (Convention No. 52). The substance of this convention has also been mentioned in the Universal Declaration of Human Rights in 1948, where it is said "everyone has the right to rest and leisure, including reasonable limitation of working hours and periodic holidays with pay".

Social tourism is in a way tied to the concept of poverty. Poverty as such may have a number of origins - it may be tied to economic crisis of the society or of an individual or a family. In every country the reactions of governments tend to 
be different (Romano 2014) and also the ways taken to alleviate poverty may be different. The social net may be dense or loose - as defined by the adopted economical strategy. In any case "social tourism" in Central European countries is very much needed.

The concept of "social tourism" has been defined in different ways, it is worth to remind some basic definitions and principles recognised by the main stakeholders. In its new statutes adopted at its last General meeting in September 2010, International Social Tourism Organization (ISTO 2011) states that social tourism can be defined as "the connections and phenomena related to the participation of people in the countries of destinations as well as of holidaymakers, of disadvantaged layers of society or those unable to participate in tourism, holidays and their advantages for whatever reason." The statutes also mention "this participation is made possible or facilitated by a combination of policies, clear social measures and the commitment of social players".

The above description explained enhanced perception from the approach that ISTO adopted initially in 2006 by European Economic and Social Committee, where is the social tourism explained and defined in narrow way, "as an activity that constitutes social tourism whenever listed conditions are met". Conditions listed included e.g. real life circumstances described as such that is totally or partially impossible to fully exercise the right of tourism (either caused by economic conditions, physical or mental disability etc.) following by condition of "definition of someone"- in being someone as public or private institution, that decides to take action to overcome obstacles preventing from exercising the right to tourism. The third and final condition described action and its effectiveness in helping the group of people to participate in tourism with strong consideration of values of sustainability accessibility and solidarity.

Although social tourism has been seen in a number of countries as having potential to counter social exclusion, formulating a definition for the term is difficult. "Social tourism" is used to describe a variety of initiatives for a variety of different social groups. The emphasized shift opened borders towards redefining social measures, and newly defining commitment of social players" (Minnaert et al. 2006).

\section{Government as Social Tourism Defender}

According the World travel and tourism council (WTTC) and their main mission in rising the awareness of Travel \& Tourism, as the one of the world's largest industries, that supports 260 millions jobs that generates 9 per cent of world GDP (WTTC, 2014) government of each state realizes its increasing importance. Looking at social tourism not only from perspective of care for disadvantaged traveller, but also as their potential employer, we must realize that is only through government and its institution we are able to secure existence and development of social tourism. Especially when in nowadays economic terms, and capitalistic profit oriented companies, represented in form of tourist agencies or any type of accommodation, transportation companies are looking for quick returns of their investment, high number of visitors, average daily rates, revenues per available room and other monetary key performance indicators that measure their "dollar" existence, are not interested or not willing to attract traveller with "low buying power" or disabled ones, where their premises are not modified towards their needs and handicaps. We observed increased awareness in attracting those travellers falling under social tourist category, in off-seasons. Whatever other example we would try to present in attempt to defend current tourism product professional deputies, as the one interested in social tourist, we would only found common denominator of all in "source of money" during the time, when "tourist with no restriction" is not likely to travel.

Business units and institutions with solely profit interest simply cannot be defending and representing interest of social tourist welfare, who by its definition falls into category of "financially low performing accounts " and this way falling out of category "source or the feeding market". Consequently it is possible to conclude, that it can only be the government and non-governmental or not for profit organizations, which genuinely care for disadvantaged social tourist, with no profit drive in their minds.

\section{Professional Bodies of Social Tourism Aiming for Welfare of all}

There would not be any "tourism for all" without the ones taking care of "welfare of all". History of travelling started during establishment of the right to travel and free time. It has finally reached professional expression in the form of organizations covering genuine interests of "the weaker ones". The International Social Tourism organization (ISTO) can be considered as the "foundation stone" of similar professional bodies.

ISTO as an international non for profit organization founded on 7 June 1963 aims at "favouring the development of social tourism in the international framework". ISTO being in charge of coordinating the tourist activities of its members, as well as informing them on all matters concerning social tourism, its cultural aspects as well as regarding the economic and social consequences of social tourism. ISTO aims at promoting access to leisure, tourism for all social levels of - 
youth, families, seniors, disabled people, and implementing this objective through the medium of state, social actors and operators. The focus on accessing and performing right of travel for all social levels is exercised in accordance with sustainability principles, securing income for the host population and respecting the cultural and natural heritage.

ISTO currently records 165 members' organizations in 35 countries (ISTO, 2014). ISTO divided its focus into following main interest groups: young adults, families facing financial challenges, people with disabilities, seniors that cannot afford travel or are daunted by the challenges connected with organizing trips.

\section{Social Tourism Development Drivers and Transnational Facilitator Exchange Platforms}

The Social Tourism European Exchanges Platform (STEEP) project was launched in April 2012 and its main objective is to create an informative and transactional platform connecting the supply and demand behind social tourism throughout the European Union. The STEEP Platform aims at facilitating transnational travel \& tourism in Europe for four target groups: seniors, youth, families and people with disabilities. The Project is now carried out by a consortium of seven European Organizations active in Social Tourism and led by the International Social Tourism Organization (ISTO).

The platform seeks to support organizations, groups and operators who plan, organize and provide travel experiences to the specific target groups by offering them quick and easy access to offers and packages across Europe. The STEEP platform also serves to educate and inform stakeholders interested in shortening the low seasonality or attracting new market segments through multiple references on Social tourism. It also contains publications, best practices, and news. It is the meeting and sales place for the large community of European social tourism stakeholders.

The STEEP platform is divided into 2 distinct areas:

Public - comprised of useful data regarding best practices, Social tourism research, Calypso initiative actions, news and current information on holiday offers (available for sale in the Private area) and other useful resources and calls.

Private - open to members it aims at bringing the offer \& demand within social tourism into one location. The tools allow for quick and simple transactions between buyers \& sellers. It is an info and sales point.

Ecalypso.eu represents the STEEP as B2B platform and as part of above described goals and objectives provides the opportunity for parallel tourism services providers to find and cooperate with each other. One service provider can promote their tourism packages completely detailed with prices and attract groups, organizations, and operators to purchase and/or promote the offers. Ecalypso.eu also helps tourism industry fill the low seasonality through creating packages for specific niche of social tourist needs. (www.ecalypso.eu)

\section{Slovakia and Social Tourism}

In the following, social tourism will be investigated in one of the regions, where the number of people and families who would need social tourism is increasing - Slovakia. Here, social tourism is in still very early development stage. Having in mind, that Slovakia with its Social Progress Index in 2014 reached 24th position out of 130 measured countries (78.93 SPI index-http://www.socialprogressimperative.org, EU-Policy department Economic and scientific Policy), it reflects large diversity of standard of living across the country. The government and private sector should be aware of benefits coming from established social tourism, but unfortunately, even in such a basic guideline document as "New Tourism Development Strategy of the Slovak republic until 2013", one will not find a single note about social tourism. We can see that the first pillars for building social tourism in Slovakia, is the Act No. 313/2005 Coll. as amended on Social Fund where it is possible to provide an employee with a contribution to a vacation from the social fund which is created from gross wages and salaries of all employees totalling to 0.6 to $1 \%$ of the initial bulk sum. As mentioned in tourism development strategy "it would be necessary to increase the minimum rate of creation of the social fund and modify the rules of the use of the financial funds for vacation of employees for purpose of supporting the domestic tourism. (New Tourism Development Strategy of the Slovak republic until 2013", Ministry of Economy of Slovak republic)

The Calypso national report on Slovakia assesses the current stage of social tourism development as "relatively new subject in Slovakia" (Calypso study on Social tourism for Slovakia, 2010, page 1-1). Calypso in its common approach towards evaluating current stage of social tourism development in EU member countries defines four main focus areas in senior citizens, young people, families facing difficult circumstances and adults with disabilities. As report concludes none of the focus group has sufficient statistical data and or specific studies carried on defined segmentation profiles in social tourism are available. Main stakeholders Ministry of Economy of Slovak republic, Slovak tourist board (SACR) and Ministry of Labour, Social Affairs and Family of the Slovak Republic, separately identified need for clear vision and implementation of social tourism in its development strategies. Currently most active facilitator is Ministry of Labour, 
Social Affairs and Family (MPSR), which financially contribute for seniors stays. National non-government organizations committed working on improvement of living conditions of the Slovak people facing difficulties also integrated tourism projects but usually as secondary objective. Most of them are grouped together in national networks such as Club of large families ("Klub mnoho detnych rodin") Youth council of Slovakia ("Rada mladeze Slovenska") Forum for help to age ("Forum pre pomoc starsim") Legislative perspective currently does not prevent social tourism and from its development in any way. MPSR and its Council for disabled citizens formed document called "National program for improvement of life conditions of disabled citizens in all aspects of life" ("Narodny program rozvoja zivotnych podmienok obcanov so zdravotnym postihnutim vo vsetkych oblastiach zivota") which sourced its direction from applying standards from United Nations for creating equal opportunities for handicapped persons. Rule 11 UN Relaxing activity and sports says: Nations will take such a measures that will secure, handicapped people with equal opportunity for relaxation and sports activity. Further on directions covers detailed definitions of steps needed for accessing the recreational and sports properties, further provides directions for tourist agencies, clubs, hotels and other creators of tourist packages to always take into consideration needs of disadvantaged travellers and similar ( http://www.nrozp.sk/files/soc_turizmus.pdf). In 2001, the following tasks have been assigned for certain sectors: mapping of current readiness of accommodation units for accessing the disabled ones, provide the services with special discounted rate for disabled citizens and to create new recondition packages stays for them, with aim of integration of disadvantaged ones (Country regional directors and mayors have been assigned for those tasks).

\subsection{Why is social tourism important in Slovakia}

The number of handicapped people as well as people cum households at risk of poverty represents a significant portion of Slovakian population. The Statistical Office of SR (2013) analysis has shown (Tab.1a) that if out of 9 indicators only 3 or 4 are used, before social transfers, material deprivation rate can be as much as $54,3 \%$. The number after social transfer (equalised disposable household incomes defined in the EU SILC survey) gives approximately $13 \%$. The data for V4 countries are shown in Tab.1b (EUROSTAT 2015). It can be seen that Slovakia comes second after Hungary in this respect. Figures 1 and 2 show the wide client basis for social tourism in Slovakia.

Table 1a. Material deprivation rate in Slovakia (2013) (Statistical Office SR 2013)

\begin{tabular}{|c|c|c|c|c|c|c|}
\hline \multicolumn{3}{|c|}{ Three items } & \multicolumn{3}{|c|}{ Four items } & \multirow{3}{*}{ Material deprivation rate } \\
\hline \multirow{2}{*}{ Total } & below & above & \multirow{2}{*}{ Total } & \multirow{2}{*}{\multicolumn{2}{|c|}{\begin{tabular}{c|r} 
below & above \\
\multicolumn{2}{|c|}{ poverty threshold } \\
\end{tabular}}} & \\
\hline & \multicolumn{2}{|c|}{ poverty threshold } & & & & \\
\hline & & & & & Total population \\
\hline 22,7 & 54,3 & 17,9 & 10,5 & 34,8 & 6,7 & Total \\
\hline 21,5 & 55,1 & 16,4 & 10,1 & 36,2 & 6,2 & Male \\
\hline \multirow[t]{2}{*}{23,9} & 53,4 & 19,3 & 10,8 & 33,3 & 7,3 & Female \\
\hline & & & & & & Age group 0 - 17 years old \\
\hline \multirow[t]{2}{*}{23,9} & 52,9 & 15,7 & 11,9 & 34,9 & 5,5 & Total \\
\hline & & & & & & Age group 18 - 64 years old \\
\hline 21,5 & 53,9 & 17,0 & 10,1 & 35,3 & 6,5 & Total \\
\hline \multirow{2}{*}{$\frac{20,8}{22,3}$} & 55,2 & 16,1 & 10,0 & 36,4 & 6,4 & Male \\
\hline & 52,7 & 17,9 & 10,1 & 34,3 & 6,6 & Female \\
\hline & & & & & & Age group 65 years old and over \\
\hline
\end{tabular}

Table 1b. Material deprivation rate in V4 countries (2012-2014). The table shows the relevant per cent of population (EUROSTAT 2015).

\begin{tabular}{|l|c|c|c|}
\hline Country & 2012 & 2013 & 2014 \\
\hline Czech Republic & 6,6 & 6,6 & 6,8 \\
\hline Slovak Republic & 10,5 & 10,3 & 9,9 \\
\hline Hungary & 25,7 & 25,8 & 23,9 \\
\hline Poland & 13,5 & 11,9 & 10,4 \\
\hline
\end{tabular}




\subsection{Organizations creating products of social tourism in Slovakia}

Among the most active institutions in social tourism are the "Slovensky zvaz telesne postihnutych" (Slovak association of handicapped people), the Narodna rada obcanov so zdravotnym postihnutim v Slovenskej republike (National league of disabled citizens in Slovakia) and Rada vlady pre problematiku obcanov so zdravotnym postihnutim. (Government league for disabled people). (Lacna, 2014). Legislation providing directions and advice in creating disabled access is explained in the "Bezbarierove zivotne prostredie" document ("Barrier free access environment" document). (NROZP, 2014).

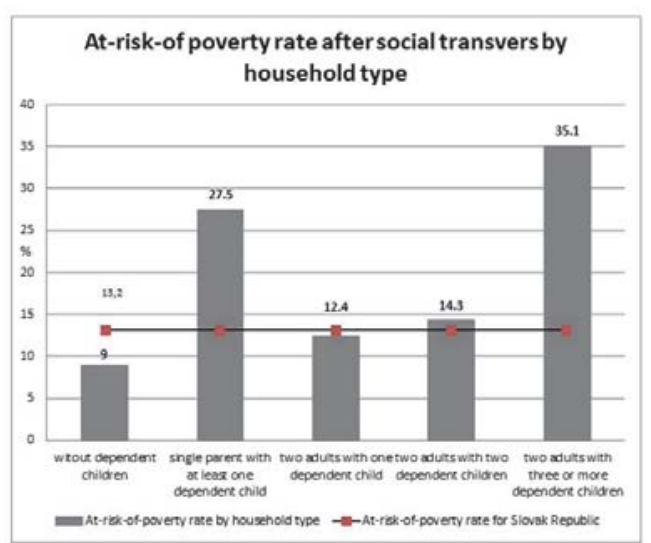

Figure 1. Measure of risk of poverty of Slovakian households according to EU SILC 2011 method ( Statistical Office 2015)

The first Slovak association of social tourism institutions, non-profit and for profit business units is the Zdruzenie Socialny turizmus (Social tourism association). Zdruzenie Socialny turizmus (ZST) is a new institutional body, born in 2011 as a brainchild of non-profit organization Domovina's founder Mr. Juraj Bena. ZST is based in the Zehra part of Hodkovce in the area of historical Csaky castle. ZST in its mission and objectives declares its interest in making accessible the historical castles and other historical monuments and monasteries in the Spis region of Slovakia to the wide public. Activities are not meant to compete with any type of traditional sightseeing, but are designed to offer additional emotional value, where one can not only expand one's knowledge about history or geography, but also recognize, and support the work of people with mental or physical handicap. Visitors can contribute by buying products, usually souvenirs, made directly by those people. This example of social tourism is not only a product of leisure business with reasonable pricing, but also a form of sightseeing in Slovakia. It is also a revenue generator for units accommodating disabled people. In addition, here we can further consider social tourism as an employment generator. ZST also claims to be active in defending social tourism and is a potential warrior against social discrimination of the disabled by the society. Its mission includes minimizing the gap and removing any barriers between people representing the majority in society and the disadvantaged ones.

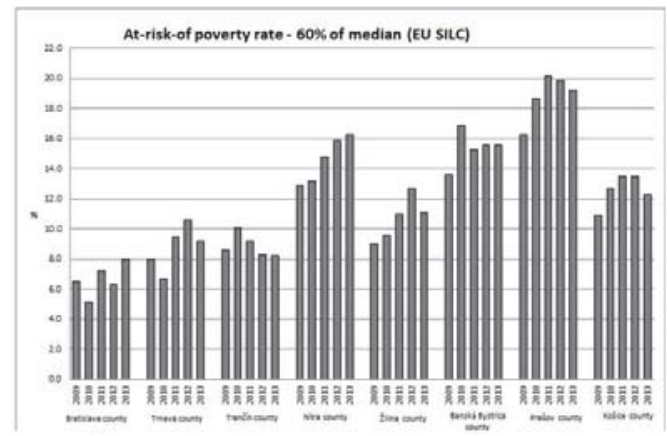

Figure 2. At risk of poverty rate distribution in Slovakian counties ( Statistical Office 2013) 
Example of coeducation facility with whole year form of stay is "Domov sociálnych služieb sv. Jána z Boha" in Spiske podhradie (DSSSPP) The social house that offers services to adult persons, whom by reason of discomforting health stage of organism or heavy handicap are dependent on help of other persons. The social house is located in two addresses with total capacity of 109 clients. Employees in total represent 59 persons out of which the majority are specialists for social care. Organizational structure is divided into three sections: economic, social work and nursing care, and restaurant. Hotel unit for supported accommodation is independent. The social house provides various supported rehabilitating therapies, where accepted person can meaningfully spend his or her time, and in meanwhile to integrate into normal life. Persons have opportunity to work in ergo-therapeutical work stations, enjoy their free time in form of active therapy and in different type of interest groups. Apart from basic sport facilities, there are special rooms with multisensory environment, stress-free focused. Hippo-therapy and physiotherapy are also available. DSSSPP apart form services provided within house areas, also organizes trips in Slovakia, an abroad to Austria Hungary, and Croatia. Worth mentioning is also part of integration process in form of different socially useful activities (from cleaning works, gardening etc) which offers certain form of income.

Other social tourism provider showing success in case of "young people" is CKM 2000 Travel. CKM is tour operator which main mission is in increasing quality of life of young people, students and teachers, through special discounts of flight bus train tickets, students exchange states, work and study programs, summer study programs and individual tourism. CKM is part of EYCA (European youth cards association and IYHF (International Youth Hotel Federation) IATA (International Air Transport association) Its services provides from 1999 and belongs to most sought after tour agencies among students (https://www.ckm.sk) .

\subsection{Refugees - new aspect of social tourism and its potential in Slovakia}

Refugees and migrants are at present within the focus of all European nations, mainly due to the unprecedented influx of Near-Eastern, Asian and African migrants. It is not understood yet, what triggered this massive flux of both political and economical migrants, but it created a need for accommodating those, who fall within the legally acceptable category. The migrants have a number of problems - different culture, religion, social skills (including language ones), labour skills, education, etc. When a society understands better the deeper aspects of social tourism one can see increased activities in accessing and inviting public and social travellers to visit refugee camps.

In this perspective we are not approaching social tourism created by traveller -"the socially disadvantaged one", but rather a general traveller visiting the socially disadvantaged ones. It is too soon to divide what is active and what would be passive part of social tourism and it might be in conflict with ethics of social tourism, to drive tourism industry into including this tourism "attracted by human sufferings " as a sources of income but it cannot be excluded as it may simultaneously bring help to migrants. Such tourism may even help to prevent activities leading to migration, as seeing the outcome of such actions and the problems it causes also at the level of receiving countries, makes it inacceptable.

Refugee camps, asylum houses, where human beings who found themselves in great life challenges is slowly becoming visible to travellers that do not seek only luxury destinations or artificial environment visited by chosen ones. The migrants, when entering a new country, have to accept fully the culture of the country and also less glittering buildings. The travellers to refugee camps usually are confronted with faces marked by tragedies and past harsh life conditions. Sometimes refugees with different cultural background can also be hostile to each other.

On example of such tourism is the Western Sahara region as described by Malainin Lakhal (Tourism watch, 2015). The Saharawi refugee camps in the South-West of Algeria are visited every year by thousands of foreigners from all over the world: politicians, NGO members, students, researchers, artists and journalists, even individuals and families from all walks of life to participate in events organized by the different Saharawi organisations and authorities, or international actors. (http://www.tourism-watch.de/en/content/tourism-western-saharan-refugee-camps) Cultural events such as film festivals are directly organized within the refugee camp. When visiting refugee camps, Lakhal points out the importance of getting the opportunity to get to know people and their life conditions, their stories and human vanity, greed and egoistic behaviour forcing them to leave their home.

Refugee camps and asylum houses in Slovakia do not currently offer such an opportunity to experience guided visits, as the total numbers of refugees are still low and the country itself is not a very attractive destination to start a new life.

In Tab.2 one can see a low interest in asylum request in the last 5 years. The most recent rush of refugees into Europe is still in progress and thus is lacking a statistical evaluation. 
Table 2: Evolution of Asylum requests in Slovakia for the period of 2011-2015; Statistical report; (Ministry of Interior of Slovakia, http://www.minv.sk/?statistiky-20)

\begin{tabular}{|c|c|c|c|c|c|c|c|c|c|c|c|c|c|}
\hline Year/month JAN FEB MAR APR MAY JUN JUL AUG SEPT OCT NOV DEC Total \\
\hline $\mathbf{2 0 1 1}$ & 33 & 43 & 29 & 22 & 37 & 39 & 43 & 41 & 49 & 73 & 52 & 30 & $\mathbf{4 9 1}$ \\
\hline $\mathbf{2 0 1 2}$ & 36 & 24 & 28 & 34 & 62 & 92 & 115 & 70 & 75 & 79 & 65 & 52 & $\mathbf{7 3 2}$ \\
\hline $\mathbf{2 0 1 3}$ & 30 & 34 & 30 & 36 & 54 & 48 & 33 & 48 & 21 & 41 & 38 & 28 & $\mathbf{4 4 1}$ \\
\hline $\mathbf{2 0 1 4}$ & 22 & 13 & 52 & 22 & 18 & 31 & 14 & 22 & 22 & 32 & 39 & 44 & $\mathbf{3 3 1}$ \\
\hline $\mathbf{2 0 1 5}$ & 16 & 12 & 36 & 10 & 23 & 12 & 13 & 8 & 10 & 14 & - & - & $\mathbf{1 5 4}$ \\
\hline
\end{tabular}

\section{Public Awareness Regarding Social Tourism}

The above mentioned organizations and institutions actively present in field of social tourism, still have not managed sufficiently to spread and increase the awareness of definition of the social tourism. According to a survey performed by a Lacna (2014), which focused on examining 19 questions investigating the level of awareness on social tourism and other selected types of tourism, only $17 \%$ of respondents were aware of social tourism (Fig.3).

Lacna`s research investigated further the main communication channels, or different types of media coverage and their share, where it is clearly visible that Internet remains the largest contributor and as second comes television (Fig.4). It means that Slovakian society is still not sufficiently aware of the needs of the at risk of poverty families and thus the wealthier segments do not support the at risk families sufficiently. This is important, as in areas, where the central sources are not able to help, the grassroot initiatives could be the best solution.

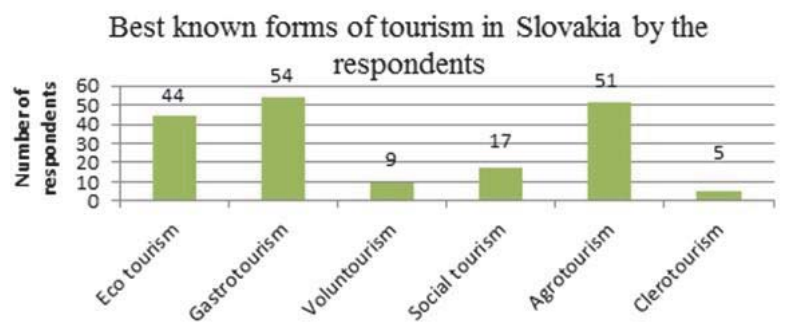

Figure 3: Best known form of tourism in Slovakia as shown in the given survey
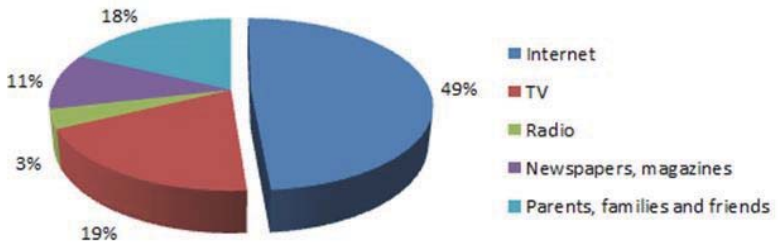

Figure 4: Promotion of Social tourism, media types coverage

\section{Social Tourism Accommodation Providers in Slovakia}

In Slovakia there is currently no profit oriented accommodation provider, that is within the Calypso initiative / STEEP (The Social Tourism European Exchange Platform) thus part of one location platform communicating the demand and offer for social tourism. Still two major hotel chains formed offer that falls under the social tourism provider definition. First one is the biggest and the oldest SOREA chain of hotels.

SOREA hotels established in 1993, and with its 13 hotels and total capacity of 3800 beds is the biggest hotel chain in Slovakia. SOREA created portfolio with majority of hotels located in nature of High and Low Tatra mountain, one spa city Piestany, and the capital - Bratislava, where offers different type of holiday packages e.g. for skiing, spa tourism, congress tourism are available. It serves around 100000 visitors per annum, where over $50 \%$ are local clients and rest foreigners mainly from surrounding countries, discovering Slovakian mountains. SOREA in cooperation with the Ministry of Labour, Social Affairs and Family created special week- packages for seniors, where government is contributing 50 
EUR per stay. This state contribution is applicable one time per year per senior, and special senior package includes 6 room night including breakfast, lunch and dinner. It is worth mentioning that this amount has been decreased from 70 EUR in 2012 into the current 50 EUR.

Other hotel chain establishment focusing on social tourism is a joint stock company HOREZZA, where the main shareholder is the state. The company name is an abbreviation of "Hotel, leisure and medical establishment", where in 4 hotels and hospitals focus is given to make mountain hotels, spa hotel, and hospital accessible for all social levels. Accommodation is being provided with very low rates also to soldiers and ex soldiers, disadvantaged people - to people with low income.

\section{Social Tourism Grants and Current Calls for Projects}

Grants as a form of financial support in social tourism, are usually provided by the Government on national level of each country, or on European level. From the perspective of EU strategy, European Commission supports social tourism e.g. trough Enterprise and industry section, through contracts and grants subsection which announces calls for proposals.

The support in Tourism section is divided into following subcategories:

1. Support for Tourism (Tourism business portal, ICT \& Tourism business initiative, Professional skills, Accessible tourism )

2. Promoting Tourism in EU (Calypso, Tourism for senior, Low season tourism: 50000 tourists - Encouraging international tourists flow to Europe, Cultural Tourism, Cycling tourism , Promoting Europe internationally, conferences)

3. European Tourism policies ( EU Policy background, Sustainable tourism)

4. Knowledge base (Virtual tourism observatory, Stakeholders, Eurobarometer surveys, tourism data)

New calls were published in October 2014 and are covering two initiatives: The report facilitating cooperation mechanisms to increase senior tourists' travels within Europe and from third countries in the low and medium seasons and Annex 1 "Demographic change and the rise of senior tourists", drafted by a group of experts, gathers knowledge on the senior tourism market. Its objective is to set up recommendations for strategic actions, identifying the role that different actors might play in their implementation. The senior initiative is a follow up of the Calypso initiative which clearly highlighted how senior tourism can contribute to combat seasonality, strengthening the notion of European citizenship and promoting a regional development (http://ec.europa.eu/enterprise/sectors/tourism)

\subsection{Successful examples of good practices}

Calypso - as mentioned - being the STEEP platform, in its mission and objectives defines its roles also in communicator and an advisor on best practices in supporting and further development of social tourism. This is presented in "Calypso study compendium of good practices", where reports is divided based on target groups of social tourism in predefined format with standard structure of informants through target group and description of exchange, support and funding mechanism, concluded in "lesson learned" field. Tab.2 shows the implementation of international tourist exchange, that has potential to be transferred to European / Calypso level.

Table 3: Holidays for Latvian low-income families to Czech Republic, Slovakia and Hungary

\begin{tabular}{|l|l|}
\hline \multicolumn{2}{|c|}{ Holidays for Latvian low-income families to Czech Republic, Slovakia and Hungary } \\
\hline Name of expert conducting research & Gunita Kakteniece \\
\hline Country & Latvia \\
\hline Respondents/informants & Tourism company "IMPRO CELOJUMI“ (Impro travels) Ltd. Ms.Arta Mende \\
\hline Target group involved & Families with children facing difficult circumstances, namely, with having a limited income \\
\hline Description of exchange & $\begin{array}{l}\text { Three travel packages - to the Czech Republic, Slovakia and Hungary - have been offered to } \\
\text { families with low income. These have been initiated and specifically tailored for this target group } \\
\text { in terms of price by the private tour company Impro Travels in } 2008 \text { and offered in summer and } \\
\text { during other school holidays. The tour operator did not profit from organising these tours, } \\
\text { whereas it positioned itself as an affordable and socially active tour operator. } \\
\text { A total of 20 three to six days trips were organised involving 350 families and a total of } 800 \\
\text { persons. The trips were organised during the peak season and they were open to all families } \\
\text { that were interested in low budget travels for families. }\end{array}$ \\
\hline Handling of target group needs & $\begin{array}{l}\text { The proposed itinerary was tailored to the interests of both children and their parents; } \\
\text { The trip was planned a bit shorter than usual to make it cheaper and bearable for children; }\end{array}$ \\
\hline
\end{tabular}




\begin{tabular}{|l|l|l|l|}
\hline & $\begin{array}{l}\text { The price for the trip was made equal to its actual costs thus making it affordable for low-income } \\
\text { families. }\end{array}$ \\
\hline Description of support mechanisms & $\begin{array}{l}\text { Organisation of these trips has been solely the initiative of Impro Travels and did not involve any } \\
\text { state or other public funding. The tourism product did not bring any profit to the company. It can } \\
\text { be considered as a good marketing tool for communicating the image of socially responsible } \\
\text { touroperator instead. }\end{array}$ \\
\hline Description of funding mechanisms & $\begin{array}{l}\text { Subsidy } \\
\text { Mechanism } \\
\text { (state/publc): N/A }\end{array}$ & $\begin{array}{l}\text { Own contribution- from participants } \\
\text { Participants covered alternate expenses of } \\
\text { the tour packages }\end{array}$ & $\begin{array}{l}\text { Other funding- not } \\
\text { state/public } \\
\text { The company covered all the } \\
\text { fixed costs }\end{array}$ \\
\hline Lessons learned & $\begin{array}{l}\text { Private initiatives play an important role in stimulating social tourism and therefore need to be } \\
\text { encouraged. Good example of the supply matching the demand. } \\
\text { This initiative can definitely be transferred to European/Calypso level. It would require initiative } \\
\text { of the tour operators and strong motivation for organising tours without any profit. In principle, } \\
\text { this margin can be subsidised by other public- state, municipal or EU funding although might be } \\
\text { a subject of conflict of interest. }\end{array}$ \\
\hline
\end{tabular}

Source: Calypso Study Compendium of good practices, DG Enterprise, March 2010 http://ec.europa.eu/enterprise/sectors/tourism/files/docs/calypso/calypso_compendium_of_good_practices_en.pdf

\section{Benefits of Social Tourism}

Recognition of benefits of social tourism has been a frequently discussed topic on all social levels. Professional institutions have been mentioning and monitoring its impact from 1970s ( e.g. de Kadt, 1979; Lea 1988; Smith \& Eadington 1990) where with time, new forms of tourism have been identified within sustainability mission such as ecotourism, pro-poor tourism, where economic benefits received by destination communities became of big concern (Murphy 1994, Ashley C. \& Goodwin H. 2000). Further on, in the report of the UN General secretary report from 2003, it was stressed that: "expression of freedom by nature and an international phenomenon by definition, tourism has everything to gain from the conquest from extensive new territory in the realm of freedom" (Secretary General, UNWTO, 2003:2).

Well-being enhancement or benefits, coming from social tourism can be divided into several subcategories. From the point of ISTO which clearly identified them in its Montreal Declaration "Towards a humanist and social vision of tourism" adopted in 1996, benefits are explained in following categories:

Social tourism is "a shaper of society" and it is clearly stated "that holidays and travel can provide particularly occasions for personal enrichment, through the discovery of new places, cultures and civilizations, through physical, artistic, sport and leisure activities, by meeting people across educational or generation divides, and by other responsibilities taken on freely by tourists".

Social tourism is a promoter of economic growth: "tourism for all is a key to economic strength which generates a continuous flow of people and investment, which contributes to regional development, produces national and international wealth and stimulates the transfer of resources from the richer economies to the poorer countries".

Social tourism participates in the regional and local development: "long before its promotion by international organisations, the concept of sustainable development had been adopted by social tourism and expressed in the following aims: reconcile tourism development, environmental protection and a respect for the identity of local communities; bring fresh resources into neglected resources; promote development without depletion of resources; generate local and economic, social and cultural benefits".

Social tourism is a partner in global development programs: "tourism, when it is controlled and when it respects the natural and cultural environment and local communities, constitutes one of the economic, social and cultural hopes of many developing countries". (The social and economic benefits of social tourism, ISTO 2011)

Other approach to defining and categorizing benefits of social tourism would be based on the subject of applied effects of social tourism.

Here we can talk about an individual with intangible benefits such as the socio-cultural benefits, mainly described by realization of valuing different cultures, endogenous products, arts and tradition, minimizing social exclusion, material deprivation and health benefits found in stress escape and rejuvenation.

The second category would represent tangible benefits found in economic benefits, mainly described by prolonging the one season in tourism, increasing the product and service income, creating employment opportunities, and state income. 


\section{Transition from Social Tourism To the "Tourism for All" Redefined}

Understanding better the current society, observing deeper all aspects of distances in wellbeing of all individuals and nations in today's world, aiming for maximizing economical results in its product tool called globalization, corporations, United states, European union; all bodies created with common effort by a power of unifying, must see social tourism as "glue" for its differentiated society, "ascending" into the desired strong and bigger "One".

Ascent comes from Latin ascendere, in translation means to climb and has to do with physical or psychical movement upwards. Ascent is usually associated with emergence, elevation, and sublimation, freedom from what weights one down. Ascension often posits hierarchy of values. Something is seen as ascending from lower, heavier, darker, more primitive state to something increasingly higher, lighter, more refined or more intelligent. In some symbolic systems, ascent must be followed by descent and vice versa, in an equalizing of unequal opposites towards the goal of self-integrity. Ascent is always paired with descent in initiatory rites and psychic processes of transformation. So this can be observed also in case of the development of social tourism.

\section{Conclusions}

Social tourism is a tool for equalizing the physically or psychically wounded ${ }^{1}$ and at risk of poverty individuals as well as households, with currently unwounded and "above the risk of poverty" majority of society. The ultimate goal of social tourism is in the ceasing of having those in risk of poverty, what will appear in the moment, when the distance between the wounded and unwounded ones would reach zero . Zero distance is the point of completed process of assimilation of wounded and needy ones with unwounded and relatively wealthy part of the society, where perception and manifestation of reality will ascent to a point where the hierarchy of values will not be measurable and segregated. In current terms it means the old ones from young ones or poor ones from rich ones, disabled ones from healthy ones. Here the an individual would be understood as an integral part of the society. Key performance indicator of successful implementation of social tourism - apart from statistics - will be the peoples' barometer measuring the state of freedom, defined and perceived by how obstructive are the unwounded and wealthy ones towards the wounded and at-risk-of-poverty ones.

All the above described initiatives form a tool for achieving the above mentioned goal. The need for social tourism could emerge also from the fall of social programs of European governments due to debt restructuring or due to increased number of seekers of employment. In Europe the influx of refugees could create an even greater need for social tourism if the refugees are to be integrated into the receiving societies.

As the number of people in risk of poverty increases both in Slovakia and the surrounding V4 countries, project based actions initiated by the government and NGOs, with EU support should help to make tourism for all available for the underprivileged at a proportion that would be visible also through national statistics.

\section{References}

Ashley,C., Boyd,C.and Goodwin,H.(2000) Pro-Poor Tourism: Putting Poverty at the Heart of the Tourism Agenda, Natural Resource Perspectives, Number 51. London: Overseas Development Institute (ISBN 1845410750)

Calypso study on Social Tourism in Slovakia, Country study, Détente Consultants, European commission, available at: http://ec.europa. eu/enterprise/sectors/tourism/files/calypso/country-reports/slovakia_en.pdf [cit. 22 -09-2014]

Domov soc. služieb sv. Jána z Boha, available at: http://www.dssspp.sk [cit. 22 -09-2014]

HOREZZA hotels, available at: http://horezza.sk [cit. 23 -09-2014]

European commission - Calypso Study- Compendium of good practices, DG Enterprise, March 2010, available at: http://ec.europa.eu/ enterprise/sectors/tourism/files/docs/calypso/calypso_compendium_of_good_practices_en.pdf [cit. 24 -09-2014]

EUROSTAT 2015: http://ec.europa.eu/eurostat/statistics-explained/index.php?title=Material_deprivation_statistics_-_early_results\&oldid $=238677$

International Labour organization, available at: http://www.ilo.org/dyn/normlex/en/f?p=NORMLEXPUB:12100:0::NO::P12100_ INSTRUMENT_ID:312197 [cit. 21-09-2014]

International social tourism organization, available at: http://www.oitsisto.org/en/index.php [cit. 21-09-2014]

ISTO. The social and economic benefits of social tourism, Social tourism enquiry; Submission of International Social Tourism Organization 2011: available at: http://nationbuilder.s3.amazonaws.com/appgonsocialtourism/pages/23/attachments/original/ ISTO_-_Inquiry_Social_Tourism.ISTO.pdf?1314889615 [cit. 22-09-2014]

Kadt E. J. de (1979) World Bank, Unesco, Publisher for the World Bank and Unesco [by] Oxford University Press, 29.11.1979

${ }^{1}$ Wound, from old English wundian, is laceration or breach (Barnhart, 889) in the physical body or psychic tissue. "Trauma" is the Greek word for wound, which also means to hurt or damage of things, and heavy blows or defeat in war (Lidel, 1881) 
Lačná L'. (2014), Socialny turizmus (Social tourism). In: Bachelor degree thesis, Technicka Univerzita v Kosiciach, Fakulta Banictva, Ekologie, Riadenia a Geotechnologii, Kosice, Slovakia

Lea, J.: Tourism and Development in the Third World, London Routledge,1988

Ministry of Labour, Social Affairs and Family of Slovak Republic, available at: http://www.employment.gov.sk/sk/ [cit. 22 -09-2014]

Ministry of Interior of Slovak Republic, Asylum Section Statistics, available at: http://www.minv.sk/?statistiky-20 [cit. 20 -06-2015]

Tourism watch: Tourism in Western Saharan Refugee Camps available at: http://www.tourism-watch.de/en/content/tourism-westernsaharan-refugee-camps [cit. 22 -06-2015]

Minnaert L., Maitland R., Miller G.(2006): Social Tourism and its Ethical Foundations, Tourism Culture \& Communication, Volume 12, Number 7, pp.7-17

Murphy, P.E. (1994) Tourism and sustainable development. In: W.Theobold (Ed.) Global tourism: The next decade, Oxford, UK ,Butterworth Heinemann, p. $273-290$

New Tourism Development Strategy of the Slovak republic until 2013, Ministry of Economy, available at: http://www.economy.gov. sk/home/126312s [cit. 24 -09-2014]

Romano S.: The political and social construction of poverty; Central and Eastern European countries in transition; Policy Press, Bristol (see at https://books.google.sk/books?id=vlHqAgAAQBAJ\&pg=PA183\&lpg=PA183\&dq=material+deprivation+rate+in+Slovakia\& source=bl\&ots=Emzlf-

MCYj\&sig=CDWLhtFU27ibP0STsNuMLAcb1AY\&hl=sk\&sa=X\&ved=0ahUKEwi2trPN5t3JAhUnjXIKHSnvAIUQ6AEIVDAG\#v=one page\&q=material\%20deprivation\%20rate\%20in\%20Slovakia\&f=false)

Ronneber A. (2010), The Archive for research in archetypal symbolism, Taschen Koln Germany, p. 430-734

SACR Slovak national tourist board, available at: http://www.sacr.sk/en/slovak-tourist-board/news/ [cit. 22 -09-2014]

Secretary General UNWTO (2003) Report of the Secretary-General, Addendum 1,

Liberalization of Trade in Tourism Services. A/15/ 7 Add.1, Madrid, September 2003. 15 th session, Beijing, China, 19-24 October 2003, Provisional agenda item 7

Slovak council for disabled, available at: http://www.nrozp.sk/files/soc_turizmus.pdf [cit. 22 -09-2014]

Slovak association of handicapped people, available at: http://www.sztp.sk/ [cit. 22 -09-2014]

Slovak social tourism association, available at: http://www.socialnyturizmus.sk http://www.sztp.sk/ [cit. 22 -09-2014]

Slovak Statistical Office; Statistical yearbook for 2014 published in 2015; available at: $h$ ttps://slovak.statistics.sk/wps/portal/!ut/p/b1/

Smith, V.L. and Eadington, W.R. (eds) (1992) Tourism Alternatives: Potentials and Problems in the Development of Tourism. Philadelphia: University of Pennsylvania Press.

Social tourism exchange platform, available at: http://ec.europa.eu/enterprise/sectors/tourism/calypso/activities/documents_calypso/ steep_summary_en.pdf [cit. 22 -09-2014]

SOREA hotels, available at: http://www.sorea.sk [cit. 23 -09-2014]

SPI Social Progress Imperative index, available at: http://www.socialprogressimperative.org/data/spi [cit. 22 -09-2014]

Statistical Office of SR: Poverty indicators and social exclusion. 2013 Available at: http://www.statistics.sk/pls/elisw/casovy_Rad.procDlg

Tourism watch: Tourism in Western Saharan Refugee Camps available at: http://www.tourism-watch.de/en/content/tourism-westernsaharan-refugee-camps [cit. 22 -06-2015]

World tourism council, available at: http://www.wttc.org/ [cit. 21-09-2014]

Youth council of Slovakia, available at: http://mladez.sk/rms/english/ [cit. 22 -09-2014]

Youth travel agency CKM200Travel, available at: https://www.ckm.sk [cit. 23 -09-2014] 